\title{
Effect of CAMELS Ratio on Indonesia Banking Share Prices
}

\author{
Mulyanto NUGROHO' ${ }^{1}$, Abdul HALIK ${ }^{2}$, Donny ARIF ${ }^{3}$ \\ Received: August 01, 2020 Revised: September 28, 2020 Accepted: October 05, 2020
}

\begin{abstract}
The research was conducted with the aim of knowing the effect of the CAMELS ratio either partially or simultaneously on stock prices. The CAMELS ratio (Capital, Asset Quality, Management, Earning, Liquidity) is used to measure the soundness of a bank, where by the better the soundness of the bank, the more profitable the bank will be for potential investors and other interested parties. The population of this research consists of the four state banks documented on the Indonesia Stock Exchange over the 2012-2019 period. The sample selection technique is a saturated sampling. This study provides the results that partially CAR has a significant effect on the share price of government banks listed on the IDX. Meanwhile, NPL, NPM, ROA, and LDR do not have a significant effect on stock prices of state banks listed on the IDX. The results of the regression analysis show that, together the CAMELS ratio, which is proxied by CAR, NPLS, NPM, ROA, and LDR has a positive and significant influence on the share price of state-owned banks documented on the Indonesia Stock Exchange, so this can be used as a reference for investors in predicting the share price of a state-owned bank before investing in shares.
\end{abstract}

Keywords: Camels Ratio, Banking, Stock Market, Share Prices

JEL Classification Code: B26, E58, G24, G33

\section{Introduction}

In the era of the world economy with capital markets, business groups or entrepreneurs function as intermediary organizations capable of mobilizing resources (Avramidis et al., 2020). The capital market provides information regarding the financial statements of listed companies, capital market rumors, policies from management, advice from brokers, prospectuses, and other information. The share of economic risk from the economic value that has internal capital market equality increases when external financing is too expensive (Claessens et al., 2006). Financial instruments

${ }^{1}$ First Author and Corresponding Author. Associate Professors, Faculty of Economics and Business, Universitas 17 Agustus 1945 Surabaya, Indonesia [Postal Address: Jalan Semolowaru No. 45, Menur Pumpungan, Kec. Sukolilo, Surabaya, Jawa Timur 60118, Indonesia] Email: nugroho@untag-sby.ac.id

${ }^{2}$ Associate Professors, Faculty of Economics and Business, Universitas 17 Agustus 1945 Surabaya, Indonesia.

Email: halik@untag-sby.ac.id

${ }^{3}$ Lecturer, Faculty of Economics and Business, Universitas Maarif

Hasyim Latif, Indonesia. Email: doni_arif@dosen.umaha.ac.id

(c) Copyright: The Author(s)

This is an Open Access article distributed under the terms of the Creative Commons Attribution Non-Commercial License (https://creativecommons.org/licenses/by-nc/4.0/) which permits unrestricted non-commercial use, distribution, and reproduction in any medium, provided the original work is properly cited. that are transacted in the capital market are called long-term instruments, which consist of bonds, stocks, rights issues, warrants, mutual funds, and various derivative instruments. The capital market has an important influence on the development of the country's economy because the capital market is an investment vehicle for investors and a source of capital for listed companies that sell them on the capital market. Indonesia has a capital market called the Indonesia Stock Exchange (IDX).

Investments in shares in publicly-traded companies promise two benefits in the form of dividends and capital gains. To get a profit or profit from investing in shares, investors must be able to read the financial reports of the issuing company and know the development of their share prices. Banking stocks are one of the most popular stocks. But banks have inherently poorer information than any other economic activity in general (Blau et al., 2016). Sources of stock price information are key to understanding the role that stock market behavior plays (Abedifar et al., 2020). Improved performance and achievement of good results have encouraged investors to re-invest in the banking sector. The most powerful assessment of providing stock price information found in the literature is the synchronization of stock returns, and that is the joint movement of the market with individual stock returns (Gul et al., 2010). 
The role of the bank as a distributor and collector of funds requires the trust of the public. Therefore, banks listed on the Indonesia Stock Exchange must periodically report their financial conditions. This is done so that the public as investors and potential investors can find out how the health condition of the bank, thus fostering confidence in the bank to manage public funds and become part of the banking sector by buying its shares. Banking financial performance can be measured by analyzing the ratio of bank financial statements. Investors review the bank's annual financial accounts and reports to evaluate the historical and current financial performance of a company to project the future bank's financial performance (Olokoyo et al., 2018).

The calculation of banking financial ratio analysis is based on building public trust and banking prudential principles, so that bank financial ratios are closely related to bank health (Ricketts \& Stover, 1978). There are several methods in measuring the soundness of a bank, one of which is using the CAMELS method. CAMELS framework was used by many researchers to evaluate the solvency and liquidity of commercial banks (Venkatesh \& Suresh, 2014). The CAMELS approach is internationally used as a scoring system by bank supervisors when comparing tires with six factors and is given the name CAMELS (Fares \& Nobanee, 2020). This method is very helpful for banks in conducting performance appraisals as well as helping regulators to carry out their supervisory functions (Dieu et al., 2020).

The CAMELS ratio is a bank soundness analysis method that uses several criteria, namely, Capital, Asset Quality, Management, Earning and Liquidity. Information on bank soundness is also very important for the government, creditors and potential creditors. These parties need information about the soundness of the bank to see the condition of the bank in the future regarding the benefits they will get after becoming a creditor at the bank. The CAMELS ratio model that will be used in this research are Capital Adequacy Ratio (CAR), Non-Performing Loan (NPL), Net Profit Margin (NPM), Return On Asset (ROA), and Loan to Deposit Ratio (LDR), and to determine the stock price used the closing stock price. Various previous studies that have been described above show varied results, some are influential and some show no effect. So, this study will examine more deeply the relationship between bank health as measured by the CAMELS ratio and the stock price movements.

A good financial ratio condition will have a positive effect on the company's financial condition, which of course will also have a positive effect on stock prices (Duong et al., 2020). Based on data regarding the market share of stateowned banks, the percentage of profits obtained is almost $50 \%$ of the total national profits at the beginning of 2019 ; this indicates that state-owned banks are in good financial condition, so the authors will make the financial statements of state-owned banks as objects in this study.

\section{Research Method}

The object of the author's research is the financial ratios in the CAMEL ratio of state-owned banks listed on the Indonesia Stock Exchange for the period from 2012 to 2019. The scope of this research consists of camels ratio, stock market and share prices of four state-owned banks listed on the Indonesia Stock Exchange during the 2012-2019 period, namely, PT Bank Mandiri (Persero), Tbk; PT Bank Rakyat Indonesia (Persero), Tbk; PT Bank Negara Indonesia (Persero), Tbk, and PT Bank Tabungan Negara (Persero), Tbk. This study uses a quantitative method with an associative research design. It uses as well a quantitative method, which is the technique of collecting samples with numbers to present empirical values and positive results by assuming the social world is measured through all the characteristics it has (Sjoberg \& Horowitz, 2013). The author uses quantitative methods for this research because it refers to data analysis and calculations in the form of numbers. An associate research design is a research that has the aim of analyzing the relationship or influence between one variable and another (Sjoberg \& Horowitz, 2013).

\section{Results}

\subsection{Descriptive Statistics}

Descriptive statistics aims to describe the data used in this study in the form of minimum value, maximum value, amount of data, the average value (mean), and the standard deviation of each variable.

Table 3: Descriptive Statistics

\begin{tabular}{|l|c|c|c|}
\hline & Minimum Value & Maximum Value & Average (Mean) \\
\hline CAR & $13,76 \%$ & $22,96 \%$ & $17,66 \%$ \\
\hline NPL & $1,55 \%$ & $4,30 \%$ & $2,67 \%$ \\
\hline NPM & $8,94 \%$ & $32,97 \%$ & $24,42 \%$ \\
\hline ROA & $1,12 \%$ & $5,15 \%$ & $3,08 \%$ \\
\hline LDR & $65,44 \%$ & $108,86 \%$ & $87,46 \%$ \\
\hline STOCK PRICE & 870 & 11675 & 6024,53 \\
\hline
\end{tabular}


CAR variable data shows the highest data value is $22.96 \%$ owned by state-owned banks (BRI) and the lowest data value is $13.76 \%$ (BRI). The average result of $17.66 \%$ indicates that the state-owned banks sampled in the study have met the minimum CAR set by the Bank Indonesia regulation of $8 \%$.

The average NPLS variable is $2.67 \%$ with a standard deviation of $0.82 \%$, a minimum value of $1.55 \%$ for stateowned banks (BRI), and a maximum value of $4.30 \%$ (BNI). Indicates that all state-owned banks have a good NPLS ratio of less than 5\% in accordance with Bank Indonesia circular letter No. 17/17 / DKMP dated 25 June 2015. So, that stateowned banks can be said to be in a healthy condition.

The state-owned banks sampled in the study had an average NPM value of $24.42 \%$ with a standard deviation of $5.89 \%$. The lowest score is owned by PT Bank Tabungan Negara (Persero), Tbk amounted to $8.94 \%$, in that year BTN's closing share price decreased from the previous year, while the highest value of $32.97 \%$ was owned by PT Bank Mandiri (Persero).

The ROA variable has the highest value of $5.15 \%$ owned by PT Bank Rakyat Indonesia (Persero), Tbk, and the lowest value of $1.12 \%$ belong to PT State Savings Bank (Persero). The result of the lowest value of $1.12 \%$ indicates that there are still state-owned (conventional) banks in Indonesia that have a ROA value below Bank Indonesia regulations, which is above $1.22 \%$.

Bank Tabungan Negara (Persero), Tbk, and the lowest value is $65.44 \%$ owned by PT Bank Mandiri (Persero). The average LDR is $87.46 \%$ and the standard deviation is $12.02 \%$. The maximum limit of the bank's LDR ratio is $110 \%$, so based on the above results it can be said that stateowned banks as the research sample are at safe limits.

\subsection{Multiple Regression Analysis}

Multiple linear regression can be used to find constants in the equation below, which can be described as a general equation for each " $n$ " component as shown in the equation (Frost, 2017). In this research, multiple regression analysis aims to determine the relationship between the independent variables CAR, NPLS, NPM, ROA, and LDR on the dependent variable stock prices of state-owned banks listed on the Indonesia Stock Exchange.

Table 4: Coefficient Test Results

\begin{tabular}{|l|c|c|c|}
\hline Variable & t-value & $\mathbf{\alpha}$ & Information \\
\hline CAR & 2,350 & 0,027 & Significant \\
\hline NPLS & 1,074 & 0,293 & No Significant \\
\hline NPM & 0,174 & 0,863 & No Significant \\
\hline ROA & 1,233 & 0,228 & No Significant \\
\hline LDR & 1,701 & 0,101 & No Significant \\
\hline
\end{tabular}

The test results for each independent variable will be described as follows:

\section{Capital Adequacy Ratio (CAR)}

The partial hypothesis for CAR is as follows:

The CAR variable has a sig value of $0,027<0,05$. The result of $t$-value is 2,350 with $t$-table of 1,706 . So that $\mathrm{t}$-value $>\mathrm{t}$-table, it can be concluded that CAR has a positive and significant effect on the share price of state-owned banks listed on the IDX.

\section{Non-Performing Loans (NPLS)}

The partial hypothesis for the NPLS is as follows:

The result of the partial test ( $t$ test) between the NPLS variable on the stock price shows the t-value of 1,074 with the $t$-table of 1,706 . The sig value of the NPLS variable is $0,293>0,05$.

\section{Net Profit Margin (NPM)}

The significant value of the NPM variable is $0,863>$ 0,05 , so $\mathrm{H}_{0}$ is accepted and $\mathrm{H}_{\mathrm{a}}$ is rejected. The result of the NPM t-value is 0,174 with the t-table 1,706 . So that $t$-value $<$ t-table.

\section{Return on Assets (ROA)}

The partial hypothesis for the ROA is as follows:

The ROA variable has a $t$-value of 1,233 with a t-table of 1,706 so that the $\mathrm{t}$-value $<\mathrm{t}$-table then $\mathrm{H}_{0}$ is accepted and $\mathrm{H}_{\mathrm{a}}$ is rejected. The significant value of ROA is $0,228>0,05$.

\section{Loan to Deposit Ratio (LDR)}

The partial hypothesis for the LDR is as follows:

The partial test result (t-test) between the LDR variable on the stock price shows the t-value of 1,701 with the t-table of 1,706 so that the t-table $>\mathrm{t}$-value then $\mathrm{H}_{0}$ is accepted and $\mathrm{H}_{\mathrm{a}}$ is rejected. The significant value of the LDR variable is $0,101>0,05$.

\section{Discussion}

The test results with the $t$ value indicate that the CAR value has a great influence on the purchase of state-owned bank share prices, which are registered on the Indonesian stock exchange. The CAR coefficient of 458,387 points is positive and indicates that bank capital is in a healthy condition. Good capital will improve banking performance, so that its share price will increase. The capital aspect stated in the CAR ratio indicates a higher CAR, it means the higher the ability of a bank to minimize the risk of any risky earning asset and to maximize profit. So, CAR is an important factor for investors who want to influence stocks because CAR shows the soundness of the bank in the aspect of capital.

The t-test result shows that partially NPLS has no significant effect on the share price a state-owned bank registered on the Indonesia Stock Exchange. NonPerforming Loans are a comparison between the number of non-performing loans and total loans extended; the higher the NPLS value indicates the higher the non-performing 
loans owned by the bank. The high total non-performing loans will reduce the chance for banks to earn profits so that investors will not be interested in investing their shares in banks. However, state-owned banks have a large market share in terms of assets, namely, $42.68 \%$, so that investors still feel safe despite the high NPL value of banks and do not pay attention to NPL in investment decisions.

The results show that NPM has no significant effect on the share price a state-owned bank registered on the Indonesia Stock Exchange because bank operating income is mainly derived from lending, so a large bank operating income indicates the greater the credit risk borne by the bank. Credit risks that arise include non-performing loans, nonperforming loans, and the occurrence of negative spreads.

The results showed that ROA had no significant effect on the stock prices of state-owned banks listed on the Indonesia Stock Exchange. The ROA value does not affect the ups and downs of stock prices. The profit gained from asset turnover has decreased during the turnover of the asset, so that it does not provide high earnings and results in reduced dividend rights for shareholders. Therefore, investors do not pay attention to the ROA aspect in their investment decisions.

The results of the t-test show that the LDR has no significant effect on the stock price of state-owned banks listed on the Indonesia Stock Exchange.

LDR does not have a positive and significant effect on stock prices because during the study period there was a fairly high gap between state-owned banks in channeling credit. It can be seen from the far enough minimum and maximum LDR values, namely, $65.54 \%$ and $108.86 \%$. This indicates that there are still state-owned banks that do not optimize funds from third parties, while on the other hand there are state-owned banks that are excessive in providing credit. This is what causes investors to pay less attention to the LDR ratio in investing in stocks so that the level of the LDR ratio does not affect the demand and supply of shares, which means that the LDR does not have a significant effect on stock prices.

The results of the regression analysis show that, together, the CAMELS ratio, which is proxied by CAR, NPLS, NPM, ROA, and LDR has . positive and significant effect on the share price of state-owned banks listed on the Indonesia Stock Exchange, so this can be used as a reference for investors in predicting the share price of a state-owned bank before investing in shares. Based on the test results, the effect of the CAMELS ratio on the share price of state-owned banks is $46.7 \%$, while the remaining $53.3 \%$ is influenced by other variables outside the research model. These results indicate that investors in making investment decisions consider the level of stock price fluctuation, the rate of return obtained from asset turnover, the ability of capital to guarantee risky productive assets (investment and lending), and the ability of bank liquidity by comparing the total loans extended to the number of party funds third.

\section{Conclusion}

The magnitude of the influence of the CAMELS ratio, which is proxied by the supporting variables of CAR, NPLS, and LDR together on the share price of state-owned banks, is $46.7 \%$, the remaining $53.3 \%$ is influenced by other variables outside the research or outside the regression equation. The simultaneous hypothesis testing results show that the CAMELS ratio is proxied by the CAR, Non-Performing Loans (NPLS), NPM, Return On-Asset, and LDR together has a good (positive) and significant effect on the share price of state-owned banks listed on the Indonesia Stock Exchange. This is indicated by the result of the t-value of 6.424 , which is greater than the t-table of 2.59 and the significance value of 0.001 , which is smaller than the significance level of 0.05 .

The results show that partially the Capital Adequacy Ratio (CAR) has a. positive and significant effect on the share price of state-owned banks listed on the Indonesia Stock Exchange. The state-owned bank with the best average CAR is Bank BRI, Tbk, with an average of $18.40 \%$ during the eight years of the study period, second place is occupied by the BNI, Tbk, with an average of $17.7 \%$, the third-order is the Bank Mandiri, Tbk, with an average of $17.54 \%$, and the last order is BTN, Tbk, with an average of $16.99 \%$, all during the eight years of the research period.

\section{References}

Abedifar, P., Bouslah, K., \& Zheng, Y. (2020). Stock Price Synchronicity and Price Informativeness: Evidence from a regulatory change in the U.S. Banking Industry. Finance Research Letters, 101678. https://doi.org/10.1016/j.frl.2020.101678

Abou-El-Sood, H. (2016). Are regulatory capital adequacy ratios good indicators of bank failure? Evidence from US banks. International Review of Financial Analysis, 48, 292-302. https://doi.org/https://doi.org/10.1016/j.irfa.2015.11.011

Alper, K., \& Çapacığlu, T. (2018). The Dynamics of Loan-toDeposit Ratio in Turkey: Who is in the Driver Seat? https://doi. org/10.13140/RG.2.2.34884.88968

Anastasiou, D., Louri, H., \& Tsionas, M. (2019). Nonperforming loans in the euro area: Are core-periphery banking markets fragmented? International Journal of Finance and Economics, 24(1), 97-112. https://doi.org/10.1002/ijfe.1651

Arif, D., Yucha, N., Setiawan, S., Oktarina, D., Martah, V., \& Muttaqiin, N. (2020). Applications of Goods Mutation Control Form in Accounting Information System: A Case Study in Sumber Indah Perkasa Manufacturing, Indonesia. Journal of Asian Finance, Economics and Business, 7(8), 419-424.

Avramidis, P., Asimakopoulos, I., Malliaropulos, D., \& Travlos, N. G. (2020). Do banks appraise internal capital markets during credit shocks? Evidence from the Greek crisis. Journal of Financial Intermediation, December 2019, 100855. https://doi. org/10.1016/j.jfi.2020.100855 
Baldwin, K., Alhalboni, M., \& Helmi, M. H. (2019). A structural model of "alpha" for the capital adequacy ratios of Islamic banks. Journal of International Financial Markets, Institutions and Money, 60, 267-283. https://doi.org/10.1016/j.intfin.2018.12.015

Blau, B., Brough, T., \& Griffith, T. (2016). Bank Opacity and the Efficiency of Stock Prices. Journal of Banking \& Finance, 76. https://doi.org/10.1016/j.jbankfin.2016.11.026

Claessens, S., Fan, J. P. H., \& Lang, L. H. P. (2006). The benefits and costs of group affiliation: Evidence from East Asia. Emerging Markets Review, 7(1), 1v26. https://doi.org/10.1016/j. ememar.2005.08.001

Dieu, H., Nguyen, H., \& Dang, V. D. (2020). Bank-Specific Determinants of Loan Growth in Vietnam : Evidence from the CAMELS Approach. 7(9), 179-189. https://doi.org/10.13106/ jafeb.2020.vol7.no9.179

Duong, T. T. N., Phan, H. T., Hoang, T. N., \& Vo, T. T. T. (2020). The Effect of Financial Restructuring on the Overall Financial Performance of the Commercial Banks in Vietnam. The Journal of Asian Finance, Economics and Business, 7(9), 75-84.

Frost, T. (2017). Quantitative Analysis. Cambridge, MA: Academic Press. https://doi.org/10.1016/B978-0-12-803224-4.00263-6

Gul, F., Kim, J.-B., \& Qiu, A. (2010). Ownership Concentration, Foreign Shareholding, Audit Quality, and Stock Price Synchronicity: Evidence From China. Journal of Financial Economics, 95, 425-442. https://doi.org/10.1016/j. jfineco.2009.11.005

Islamic Financial Services Board. (2015). Islamic Financial Services Industry Stability Report 2015. In: Annual Report.
Karadima, M., \& Louri, H. (2020). Economic policy uncertainty and non-performing loans: The moderating role of bank concentration. Finance Research Letters, 101458. https://doi. org/10.1016/j.frl.2020.101458

Rachman, R. A., Kadarusman, Y. B., Anggriono, K., \& Setiadi, R. (2018). Bank-specific Factors Affecting Non-performing Loans in Developing Countries: Case Study of Indonesia. Journal of Asian Finance, Economics and Business, 5(2), 35-42.

Ricketts, D., \& Stover, R. (1978). An examination of commercial bank financial ratios. Journal of Bank Research, 9, 121-124.

Rubinshtein, E., Saltykov, M., Nagapetyan, A., Dyachenko, Y., \& Brizitskaya, A. (2017). Comparison of banks of China and Australia by Return on Assets and Capital. https://doi. org/10.2991/ttiess-17.2017.92

Sjoberg, L., \& Horowitz, J. (2013). Quantitative methods. Critical Approaches to Security: An Introduction To Theories and Methods, 103-117. https://doi.org/10.4324/9780203076873

Venkatesh, D., \& Suresh, C. (2014). Comparative Performance Evaluation of Selected Commercial Banks in Kingdom of Bahrain Using CAMELS Method. SSRN Electronic Journal. https://doi.org/10.2139/ssrn.2418144

Warrad, L. (2014). The Effect of Current Ratio on Jordanian Real Estate Sector's Net Profit Margin. European Journal of Economics, Finance and Administrative Sciences, 35-39.

Wuryani, E., Fathoni, A., Sutarsi, S., Nurna, N., \& Arif, D. (2021). Analysis of decision support system on situational leadership styles on work motivation and em-ployee performance. 11 . https://doi.org/10.5267/j.ms1.2020.9.033 
